\title{
衝撃波の入射位置が壁面燃料噴射場における燃焼と流れ場に及ぼす影響*1 Effect of the Location of an Incident Shock Wave on Combustion and Flow Field of Wall Fuel-Injection
}

\author{
中 村 寿*2 ·佐 藤 直 樹*2 $\cdot$ 小林 秀 昭*2 升 谷 五 郎*3 \\ Hisashi Nakamura, Naoki Sato, Hideaki Kobayashi and Goro MasuYa
}

Key Words : Compressible Flow, Shock Waves, Combustion

\begin{abstract}
Experimental and numerical studies of the interaction between combustion of a hydrogen jet and an incident shock wave were performed. In the case that an incident shock wave was introduced upstream of the injection slot, the boundary-layer separation region was extensively expanded. The penetration height of the Mach disk with an incident shock wave was less than that without an incident shock wave. Combustion was confirmed when the incident shock wave was introduced downstream of the fuel injection slot, while, with the incident shock wave upstream of fuel injection slot, combustion was not confirmed. The mechanism of these phenomena was discussed based on the results of numerical simulation in terms of the residence time in the separation region near the fuel injection slot.
\end{abstract}

\section{1. 緒言}

次世代極超音速飛翔体の推進エンジンとして , スクラム ジェットが有望視されている . スクラムジェットは大気中の 酸素を酸化剂として用い, 超音速のまま燃焼器内て燃焼す る.このため, 高マッハ数でも高い比推力を示すが, 超音 速流中における燃焼制御には困難な問題が多い . 超音速流 中における燃焼制御を複雑にする要因の一つとして，衝撃 波と燃烵場の干渉が挙げられる . スクラムジェットは広い 飛行マッ八数, 高度および迎角で動作することを要求され るため, 流入空気の条件が大きく変動する．このため，燃 焼器内の衝撃波の条件も変動し, これか燃焼場と干渉して 燃焼制御を困難にすることが予想される．

これまでに，いくつかの超音速燃焼場と衝撃波の干渉現 象に関する報告がなされている．Ratner ら ${ }^{1)}$ (同軸噴流 火炎での衝撃波との干渉現象を調へ，流れ場の構造と燃焼 領域か燃料流量によって变化することを示した . Fujimori ら ${ }^{2)}$ は超音速流中のストラット後流に形成される再循環領 域に衝撃波を入射することで，保炎限界が拡大することを 実験および数值解析により示した . Rubins ら ${ }^{3)}$ は主流方向 と平行に燃料を噴射し, 弚の下流に形成される剪断層に衝 撃波を入射することで，より低い温度で着火することを示 した . しかしながら , スクラムジェット燃焼器の最も基本 的な燃料供給法の一つである, 壁面からの燃料の垂直噴射 場（以降，壁面噴射場と称する）における入射衝撃波の影

\footnotetext{
*1 C) 2007 日本航空宇宙学会

平成 18 年 6 月 5 日原稿受理

*2 東北大学流体科学研究所

$* 3$ 東北大学大学院工学研究科
}

響を調べた研究は知見しない。

乥こで本研究では実験および数值解析を行い, スクラム ジェット燃焼器の最も基本的な形態である, 水素燃料の壁 面噴射場に衝撃波を入射し，弚の位置により流れ場と燃焼 場がどのように変化するか明らかにすることを目的とする .

\section{2. 実 験 装 置}

2.1 超音速燃焼試験設備 実験は東北大学流体科学研究 所の超音速燃焼試験設備で行った . 本設備は燃焼実験を行 う際の安全性および保守性を考慮して, ブローダウン方式 を採用している．昇温は実験前にプロパンガスバーナで加 熱した蓄熱式熱交換器で行う．ノズル出口直径は $135 \mathrm{~mm}$, 試験部はセミフリージェット方式である．本研究では主流 マッ八数を 2.5 に固定して実験を行った . 第 1 表に本実験 の主流条件を示す .

2.2 壁面噴射装置および衝撃波発生板 本研究で用い た壁面噴射装置の構造図を第 1 図に示す . 噴射口は $0.5 \mathrm{~mm}$ $\times 20 \mathrm{~mm}$ の長方形スリットで, 縮流を防ぐためにノズル形 状になっている.本研究における主流条件では水素燃料の自 着火が期待できないため，予燃焼室を設けて燃料過乘の混 合気を一次燃焼させ，燃焼生成物である過熱水蒸気を含む 高温水素を噴射させる . 予燃焼室の空間は風洞が閉塞しな い範囲で可能な限り大きく設計し，体積はおよ光 $240 \mathrm{~cm}^{3}$ である. 予燃焼室の下面には燃料配管と圧力ポート・熱電 対および電気火花式のイグナイタが取り付けられるように なっている．噴射壁と予燃焼室の前縁は圧力損失を抑える ために先端を鋭角にしている．また，噴射壁の後縁が保炎 器の代わりにならないよう，鋭角にしている．噴射壁は主 流のわずかな変動により境界層剝離が生じないよう，2。傾 
けて取り付けた .

試験部の概略図を第 2 図に示す. 衝撃波発生板は楔形状 で, 片側の偏角が $6^{\circ}$ ，もう片側の偏角が $10^{\circ}$ である. 衝撃 波発生板を裏返すことで異なる強さの衝撃波を入射するこ とができる．衝撃波発生板はアームを介してステッピング モーターを利用したアクチュエーター (駿河精機製 KS16135) に接続されており, 主流方向に動かせるようになって いる.これにより衝撃波の入射位置をブローダウン中に変 更することができる．可動距離は $30 \mathrm{~mm}$ である . 一般に， ステッピングモーターの静止トルクは強いが駆動トルクが

\begin{tabular}{lc}
\multicolumn{1}{c}{ 第 1 表 } & 主流条件 \\
\hline Mach number & 2.5 \\
Total pressure & $0.5 \mathrm{MPa}$ \\
Static pressure & $68 \mathrm{kPa}$ \\
Total temperature & $520-870 \mathrm{~K}$ \\
Static temperature & $231-387 \mathrm{~K}$ \\
Test duration & Max. $20 \mathrm{~s}$ \\
\hline
\end{tabular}

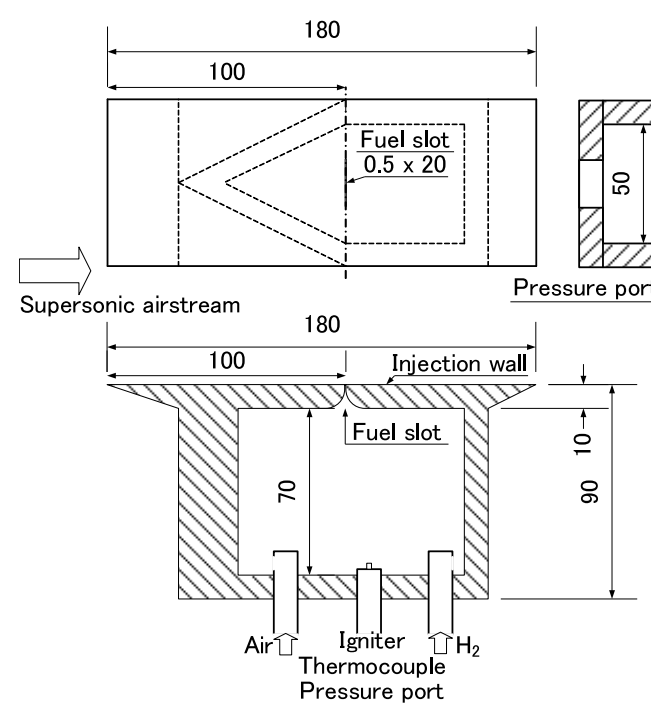

第 1 図 壁面噴射装置の構造図

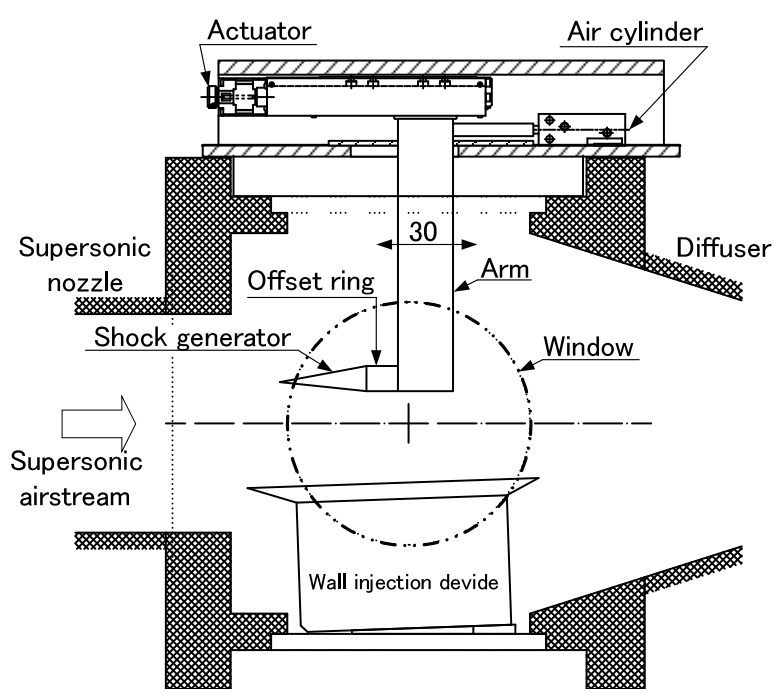

第 2 図試験部の概略図
弱い.このため，衝撃波発生板を下流から上流に超音速空気 流に逆らって動かす場合，駆動トルクが不足する場合があ る . 高駆動トルクのモーターを利用したアクチュエーター は大型化し，空間の限られた試験部に設置することが難し い. 弚こで, 本研究ではアクチュエーターの下流側にエア シリンダー (SMC 製 CU16-30D) を設置し，アームを下 流側から上流側に戻す力を強化した . エアシリンダーには ゲージ圧で $0.1 \mathrm{MPa}$ の圧力をかけた . このときのエアシリ ンダーの駆動力は $20 \mathrm{~N}$ である . 衝撃波発生板の主流方向 の配置について微調整を行うために，衝撃波発生板とアー ムの間にオフセットリングを設置できるようにした .

2.3 実験手順 超音速燃焼風洞を始動させ，主流全圧 が $0.5 \mathrm{MPa}$ になったとき圧力センサおよび熱電対の出力の 記録を開始する．非燃焼で実験する場合，壁面噴射装置の 噴射壁から空気を噴射し，シュリーレン画像の録画を開始 する．燃焼実験を行う場合，イグナイタを動作させ，噴射 壁に水素と空気を供給する。壁面噴射装置内に取り付けた 熱電対の指示值が安定した後，イグナイタを停止し，予燃 焼が安定して継続していることを確認する. 弚の後, シュ リーレン画像の録画を開始する．衝撃波発生板を用いない 場合，約 3 秒間シュリーレン画像を取得し，空気または空気 と水素の供給を停止する．衝撃波発生板を用いる場合，ア クチュエーターに動作指令を与え, 衝撃波発生板を主流方 向に沿って $3 \mathrm{~mm} / \mathrm{s}$ の移動速度で $30 \mathrm{~mm}$ 動かす . アクチュ エーターの停止を確認した後 , シュリーレン画像の録画を 停止し，空気または空気と水素の供給を停止する．

\section{3. 実験結果および計算結果}

3.1 入射衝撃波の位置が流れ場の構造に及ぼす影響 第 3 図にモノクロ CCD カメラで撮影した非燃焼場に入射衝 撃波を移動させたときのシュリーレン画像のうち，衝撃波 入射位置か噴射口の上流側と下流側にある代表的な結果を 示す. 非燃焼場の実験では水素ではなく空気を噴射させて いる．すなわち，噴射空気の全圧は $1.1 \mathrm{MPa}$ で，偏角 $6^{\circ}$ の 衝撃波発生板を上流から下流に動かした結果を示している. シュリーレン画像から，衝撃波を噴射口の上流側に入射

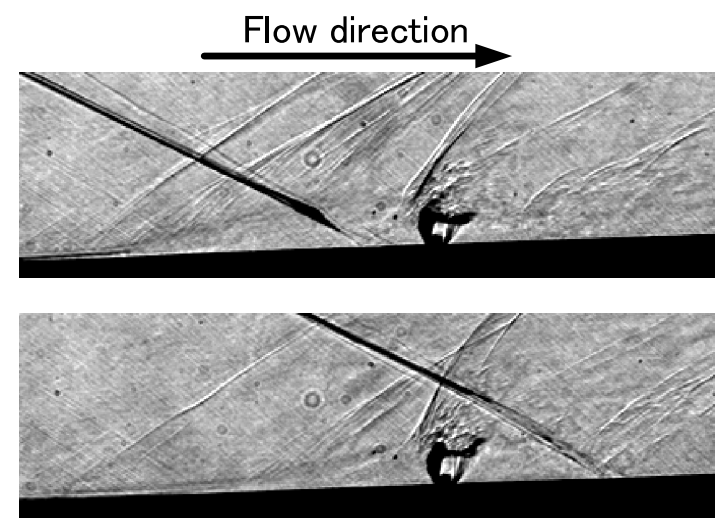

第 3 图 衝撃波の位置を変化させたときのシュリーレン画像 (偏角 $6^{\circ}$, 主流全温 $800 \mathrm{~K}$, 主流全圧 $0.5 \mathrm{MPa}$ ，噴射全圧 $1.1 \mathrm{MPa}$ ) 


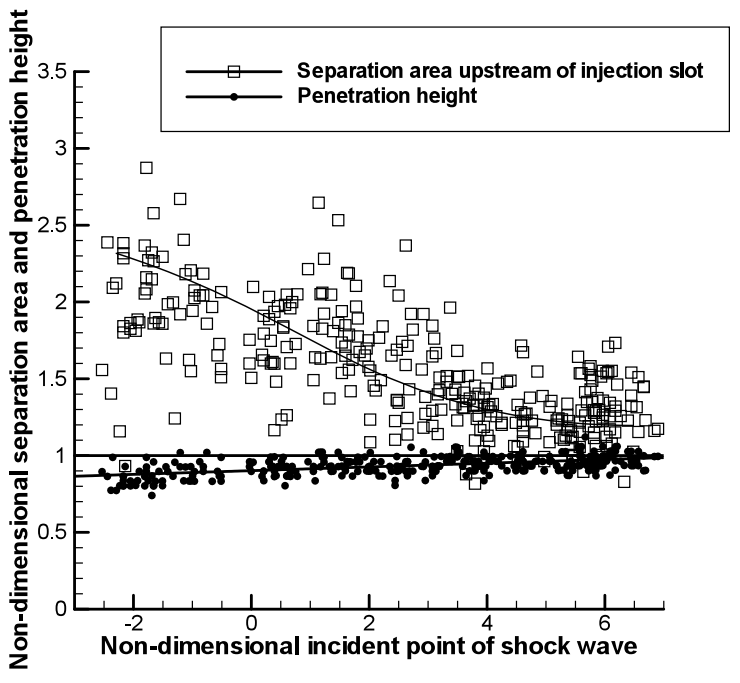

第 4 図 入射衝撃波の位置による流れ場への影響（偏角 $6^{\circ}$, 主流全温 $800 \mathrm{~K}$, 主流全圧 $0.50 \mathrm{MPa}$ ，噴射全圧 $1.1 \mathrm{MPa}$ )

したとき，噴射口上流側の剝離領域が拡大している樣子が 分かる、衝撃波を噴射口の下流側に入射すると，噴射口上 流側の剝離領域は小さくなっている樣子が分かる . また , 噴 流により発生する弓形衝撃波の形状がより垂直に近くなり， 噴流の貫通高さがやや上昇している樣子が見られる .

これらの現象をより詳しく調べるために, シュリーレン 画像から入射衝撃波の入射位置, 噴射口上流側の剝離領域 の大きさ，貫通高さを求め，第 4 図にプロットした .ここ で，衝撃波の入射位置は，入射衝撃波の延長線と壁面との 交点とし, 噴射口中心を原点として, 上流側を負，下流側 を正とした . 剝離領域の大きさはシュリーレン画像から判 別される剝離領域の面積として定義した . 貫通高さは壁面 からのマッハディスク中点までの垂直距離として定義した 彔離領域の大きさと貫通高さは，同一条件下における入射 衝撃波無しの場合の值で光れ光れ無次元化した . 入射衝撃 波の位置の無次元化には入射衝撃波が無い場合の貫通高さ を用いた . 同樣に貫通高さを用いて無次元化したシュリー レン画像の単位ピクセルあたりの空間解像度は 0.03 であ る.プロットしたデータは 10 秒間のアクチュエーターの動 作時間における，計 300 枚の画像から求めた . 無次元化に 用いた基準量は 15 枚のシュリーレン画像から求めた平均 値を用いた 。

無次元化した剝離領域の大きさは, 入射衝撃波を噴射口 の上流側に入射しているとき非常に大きく変動しているが， 下流側に入射すると光の変動幅は小さくなっている．また， 兴の值は 1 に近づいている.入射衝撃波か噴射口の上流側 に入射した場合，入射衝撃波の圧力上昇により，剝離領域 は 1.5 倍から 2 倍程度に拡大している.噴射口上流側の剝 離領域の拡大により，この領域における燃料の滞在時間が 増加し，壁面噴射場まわりの保炎に良好な影響を及ぼすと 予想される.一方, シュリーレン画像からは噴射口下流側の 剝離領域は本実験では明確にとらえることはできなかった。 無次元貫通高さは 1 より低い値となった .これは, 入射

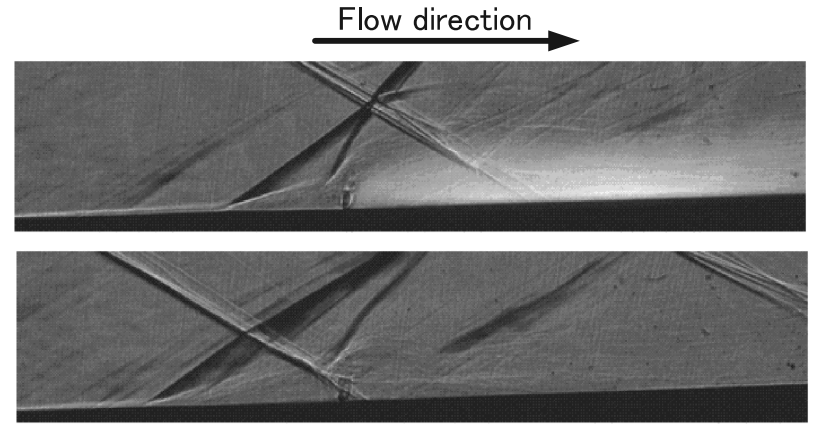

第 5 図 衝撃波入射位置による消炎 (偏角 $10^{\circ}$, 衝撃波発生板の移動 速度 $3 \mathrm{~mm} / \mathrm{s}$, 主流全温 $660 \mathrm{~K}$, 主流全圧 $0.53 \mathrm{MPa}$, 噴射全 圧 $1.2 \mathrm{MPa}$ ，噴射全温 $720 \pm 10 \mathrm{~K}$ ，予燃焼当量比 $4.8 \pm 0.2$ )

衝撃波か噴射口の上流側にあるとき，入射衝撃波の圧力上 昇によって噴流の背圧が上昇するためである . 入射衝撃波 か噴射口の下流側にあるとき，入射衝撃波と弓型衝撃波が 干渉し，弓型衝撃波の垂直衙撃波に近い強い衝撃波の部分 が長くなり，噴射流出口付近の背圧はわずかに上昇してい ると考えられる．このため，入射衝撃波か下流から上流に 移動すると，無次元貫通高さは緩やかに上昇し，1よりわ ずかに小さい值に近づくと考えられる .この貫通高さのわ ずかな減少は, 主流への燃料供給の低下を示唆している.

3.2 入射衝撃波の位置が燃焼場に及ぼす影響 第 5 图 に偏角 $10^{\circ}$ の衝撃波発生板を用いて衝撃波入射位置を变化 させながら , デジタルスチルカメラによりシュリーレン画 像と火炎を同時撮影した結果を示す．衝撃波を噴射口の下 流側に入射したとき，火炎の赤黄色発光が確認できた，光 のまま衝撃波入射位置を噴射口に向かって動かすと，火炎 の発光する領域が小さくなり，発光強度も弱くなった . さ らに，衝撃波入射位置を上流に移動させると，ある位置で 火炎の発光が全く見られなくなった . 水素拡散火炎の赤黄 色発光は水分子からの発光であり, 本研究ではこの発光が 見られなくなる状態を消炎とみなした，すなわち，衝撃波 入射位置に依存した消炎限界が存在するといえる．本研究 における実験範囲内では，衝撃波を噴射口の上流側に入射 したとき，噴射口上流側の剝離領域に大規模な再循環流が 予想されるにもかかわらず火炎の発光は確認できず，燃料 噴射口の下流側に衝撃波が入射する方が，保炎に良好な影 響を及ぼしている。

衝撃波入射位置による消炎限界の変化についてより詳細 に調べた．消炎時における主流全温と衝撃波入射位置の関 係を示したものが第 6 図である . 噴射条件はほぼ一定に保 ち，衝撃波入射位置の影響について注目した．実験中の予 燃焼当量比，噴射全温およひ噴射全圧の平均值は兰れ光れ

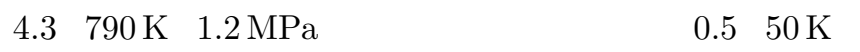
$0.4 \mathrm{MPa}$ であった . 衝撃波入射位置のエラーバーは，消炎 か観測された瞬間と光の前後 2 枚の計 5 枚から求めた標準 偏差を用いた . 本研究における実験条件では消炎限界はほ ぼ直線になっている，直線の上側が保炎領域である．主流 全温が高い領域においても，衝撃波入射位置か噴射口の上 


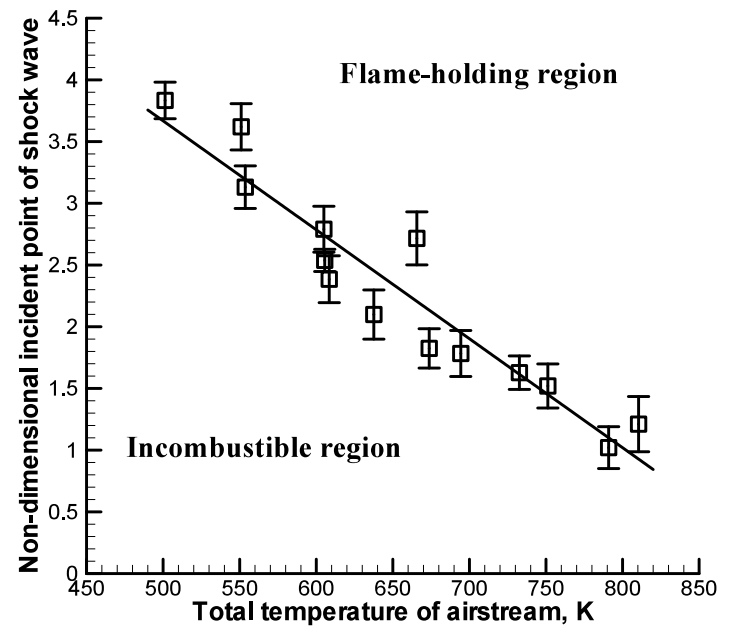

第 6 図 衝撃波入射位置を変化させたときの消炎限界（偏角 $10^{\circ}$, 噴 射全温 $790 \pm 50 \mathrm{~K}$ ，噴射全圧 $1.2 \pm 0.4 \mathrm{MPa}$ ，予燃焼当量比 $4.3 \pm 0.5)$

流側にある場合, 本研究で確認された剝離領域の大きさか ら噴射口上流側に大きな再循環領域の存在が予想されるに もかかわらず，保炎はできなかった .これは，本実験条件 において主流全温が最大 $800 \mathrm{~K}$ と低いことが原因の一つで あろ ${ }^{4)}$. 一方で，主流全温が低くとも，衝撃波入射位置 が十分下流にあれば，保炎可能であった．なお，衝撃波を 入射させなかった場合，上記噴射条件では着火および保炎 のいずれも確認できなかった .

以上述べたように，本実験条件では保炎領域は常に燃料 噴射口の下流側にあった .この結果に衝撃波入射による噴 射口上流側の剝離領域の拡大が大きな影響を及ぼしている とは考えにくく，むしろ，噴射口下流側の流れ場が重要な 役割を果たしていると考えるべきである．しかし，密度勾 配をとらえるシュリーレン法で噴射口下流側の流れ場を可 視化するには限界がある. 弚こで, 本研究ではこれ以降, 数 值解析によって特に噴射口下流側の流れ場の構造に注目し， 本実験で得られた衝撃波入射位置による保炎特性を考察す ることとする．

3.3 入射衝撃波と水素噴流燃焼の干渉現象に関する数 值解析 基礎方程式には二次元レイノルズ平均ナビエ・ス トークス方程式を用いた . 対流項には AUSM-DV 法5)，リ ミッター関数には minmod 関数を用いて最大 2 次精度の MUSCL 型空間差分を用いた . 粘性項には中心差分を用い た。生成項は点陰解法 $\left.{ }^{6}\right)$ を用いて安定化し, 時間項は陰的 に解き, 時間積分には MFGS 法》をを用いた .乱流モデルに は $k-\omega$ 二方程式モデル8) を用いた .

まず，計算結果を検証するために，第 4 図に示した実験 結果との比較を行った (第 7 図). 主流および噴流の条件， 定義と無次元化の方法は第 4 図の実験結果と同一である . 第 7 図から, 噴射口上流側の剝離領域の大きさ, 貫通高さ ともに数值計算結果は実験結果とよく一致しており，本計 算モデルはおおむね流れ場を再現できていると考えられる． 第 4 図に示した実験条件を模擬した数值解析を行い，保

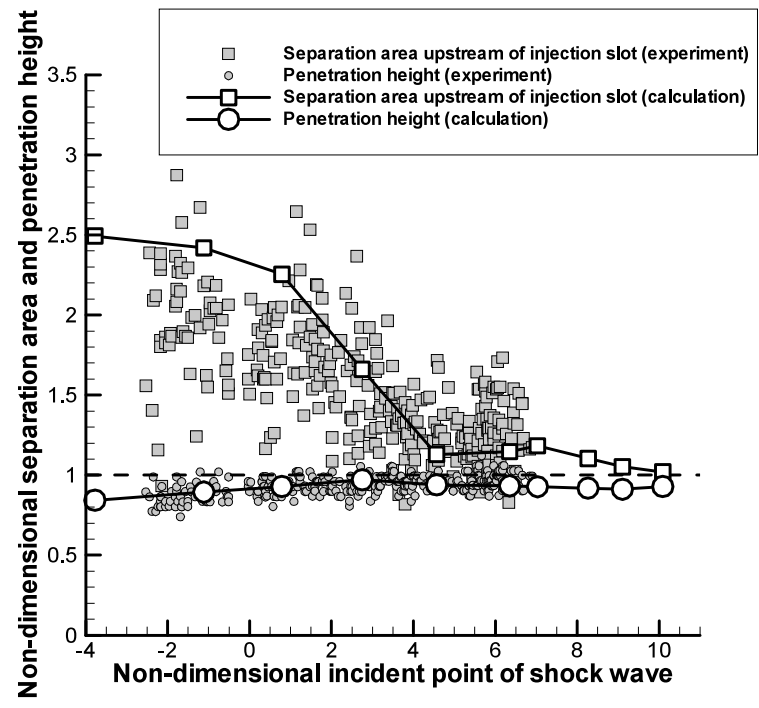

第 7 図＼cjkstart実験結果と計算結果の比較

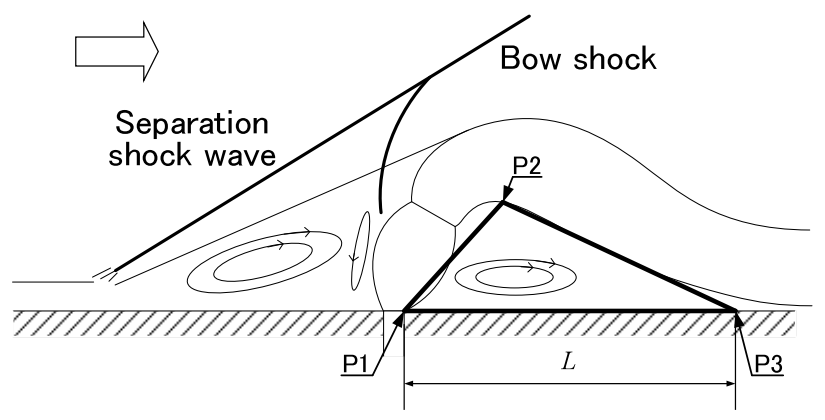

第 8 図 噴射口下流側の剝離領域の定義

炎メカニズムを調べるため，ここではシュリーレン画像か らとらえられなかった噴射口下流側の剝離領域に注目した . 第 8 図に示すように，噴射口下流側の剝離領域を三角形で 定義し，P1 と P3 間の距離 $L$ を代表長さとして定義した . また，噴射口下流側の剝離領域内の再循環流における最大 流速を代表速度 $V$ とした . 再循環流における見かけの滞在 時間 $\tau$ を $\tau=L / V$ で評価した $\tau, L, V$ の兰れ光れは入 射衝撃波が無い場合の值で無次元化して $\bar{\tau}, \bar{L}, \bar{V}$ で示す． これらを入射衝撃波の位置に対してプロットしたものを第 9 図に示す . 入射衝撃波の位置は実験と同樣に入射衝撃波 がない場合の貫通高さの計算結果で無次元化した . 入射衝 撃波の位置は実験よりも広い範囲て数值解析を行った . 入 射衝撃波の位置によらず，無次元代表流速 $\bar{V}$ は 1 に近い． 乥れでも，入射衝撃波か噴射口下流側にある場合， $\bar{V}$ はや や低下する傾向が分かる．また，衝撃波か噴射口の上流側 にある場合， $\bar{V}$ は1 1 りやや大きい值を示している.一方， 無次元代表長さ $\bar{L}$ は入射衝撃波力噴射口下流側にある場合， 急激に大きくなっている．衝撃波入射位置か噴射口上流側 にあるとき， $\bar{L}$ は 1 に漸近している．以上のことから，噴 射口下流側の剝離領域内の再循環領域における気流の無次 元滞在時間 $\bar{\tau}$ は, 衝撃波入射位置か噴射口下流側にある場 合，急激に拡大することが分かる．また，弚の拡大は噴射 


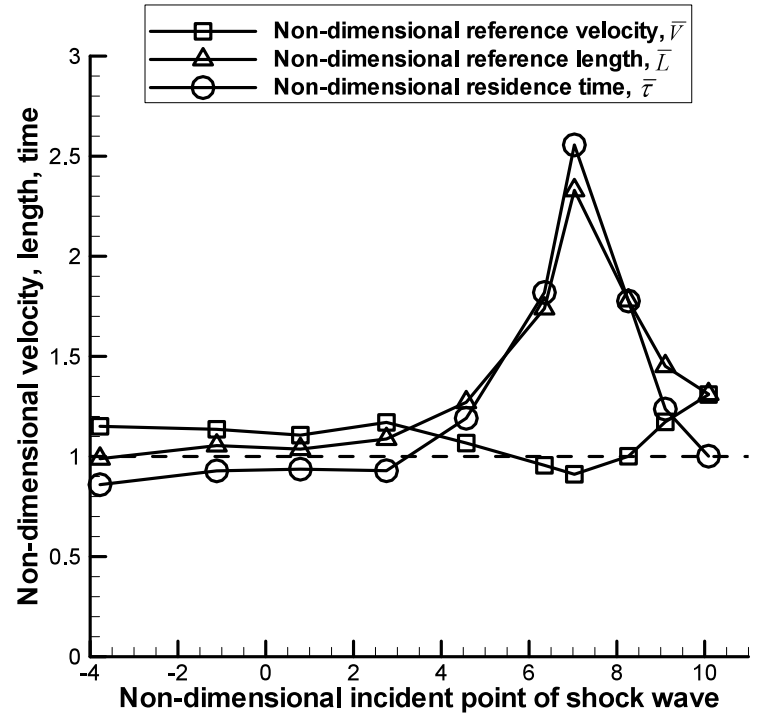

第 9 図＼cjkstart衝撃波入射位置か噴射口下流側の剝離領域に及ぼす影響

口下流側の剝離領域の無次元代表長さ $\bar{L}$ に大きく依存して いることが分かる．実験を行った無次元入射衝撃波位置は -2.5 から 6.5 であるが, さらに下流側に衝撃波を入射する と，無次元入射衝撃波位置が 7 付近で $\bar{\tau}$ が極大となる．し たがって，第 6 図で示されたように，本研究の実験範囲内 では，衝撃波がより噴射口の下流側にあるほど，低い主流 全温においても保炎に良好な影響を及ぼしていることが分 かる．一方，衝撃波入射位置が十分大きくなると $\bar{\tau}$ は減少 し， $\bar{V}$ は増加するため， $\bar{\tau}$ は 1 に近づく．衝撃波を噴射口 の十分下流に入射すると，入射衝撃波の噴流場に及ぼす影 響はほとんどなくなることが予想される .これは第 6 図に おいて，十分大きな衝撃波入射位置に対して，もう一つの 消炎限界が存在していることを示唆していると考えられる 一方，化学反応モデルとして GRI-Mech 3.0 から酸素/水 素反応を抜き出したものを用いて，化学反応を含む数値解 析を試みた . 燃料噴流の境界条件における化学組成は, 当 量比 4.8 の水素空気予混合気の平衡計算結果を用いた .し かし，実験条件を模擬した計算条件では，実験で保炎した 条件であっても数值解析では保炎できなかった．本研究の 予燃焼室の容積は風洞が閉塞しない条件下で可能な限り大 きくしたが, 光れでも予燃焼が完全に平衡に達するのに十 分な予燃焼室内の滞在時間ではない．また，予燃焼室壁へ の熱損失も無視できない．実験の燃料噴流には予燃焼で生 成された中間生成物であるラジカルが含まれており，これ らか噴射口下流側の領域に与える影響も大きいと考えられ る.これについては, 今後予燃焼室を含めた数值解析を行 うことが必要と考えられる。

$$
\text { 4. 結言 }
$$

超音速流中における壁面噴射場に斜め衝撃波を入射し，
その位置や強さにより流れ場の構造がどのように変化する かを実験および数値解析により調べた . さらに , 水素/空気 混合気を高い当量比で予燃焼させ，高温の未燃水素を噴射 し，形成される水素噴流燃焼場に及ぼす衝撃波入射位置の 影響に関する実験を行った．これらの結果から，以下の知 見を得た 。

1. 実験において，衝撃波の入射位置か噴射口の上流側に あるとき，噴射口上流側の剝離領域が拡大した . 衝撃波を 入射させると噴流の貫通高さは，入射衝撃波を用いない場 合と比較して，光の入射位置によらず低くなった．

2 . 衝撃波を噴射口の上流側に入射すると，本実験条件で は噴射口上流側の大きな剝離領域の存在にもかかわらず保 炎できなかった .一方，衝撃波を噴射口の下流側に入射す ると保炎できることが分かった．また，低い主流全温にお いても，衝撃波を噴射口の下流側に入射することで保炎が 可能であった .

3. シュリーレン画像から噴射口下流側の剝離領域は明確 にとらえられなかったが, 数値解析から，衝撃波を噴射口 下流側に入射すると，噴射口下流側の剥離領域内の再循環 流における見かけの滞在時間が増加した .このことが, 本 実験において，噴射口下流側に衝撃波を入射したとき，保 炎が可能となる原因になっていると考えられる．すなわち， 主流全温が低くても，燃料噴射口の下流側に入射された衝 撃波は保炎に有効である．

\section{参 考 文 献}

1) Ratner, A., Driscoll, J. F., Huh, H. and Bryant, R. A.: Combustion Efficiencies of Supersonic Flames, J. Propul. Power, 17 (2001), pp. 301-307.

2) Fujimori, T., Murayama, M., Sato, J., Kobayashi, H., Hasegawa, S. and Niioka, T.: Improvement of Flameholding Characteristics by Incident Shock Waves in Supersonic Flow, Combustion of Energetic Materials, Begell House Inc., Redding, CT, 2002, pp. 330-339.

3) Rubins, P. M. and Bauer, R. C.: Review of Shock-Induced Supersonic Combustion Research and Hypersonic Applications, J. Propul. Power, 10 (1994), pp. 593-601.

4) Ben-Yakar, A. and Hanson, R. K.: Experimental Investigation of Flame-Holding Capability of Hydrogen Transverse Jet in Supersonic Cross-Flow, Proc. 27th Symposium on Combustion, 1998, pp. 2173-2180.

5) Wada, Y. and Liou, M. S.: A Flux Splitting Scheme with Hight-Resolution and Robustness for Discontinuities, AIAA Paper 94-0083, 1994.

6) Eberhardt, S. and Imlay, S.: Diagonal Implicit Scheme for Computing Flows with Finite Rate Chemistry, J. Thermo. Heat Transfer, 6 (1992), pp. 208-216.

7) 嶋 英志: 構造/非構造格子 CFD のための簡単な陰解法 , 第 29 回流体力学講演会講演論文集, 1997, pp. 325-328.

8) Wilcox, D. C.: Turbulence Modeling for CFD, 2nd ed., DCW Industries, La Canada, CA, 1998.

9) Billig, F. S., Orth, R. C. and Lasky, M.: A Unified Analysis of Gaseous Jet Penetration, AIAA J., 9 (1971), pp. 1048-1058.

10) Curran, E. T. and Murthy, S. N. B.: Scramjet Propulsion, AIAA, Reston, VA, 2000. 